\title{
Pre-Concert Ritual Design and Audience Experiential Involvement in Classical Music Concert
}

\author{
Eun-Young Yang \\ Doctor of Musical Arts in Voice Performance and Literature \\ $\mathrm{Ph}$. D. in Business Administration \\ E-mail: eun0yang@ postech.ac.kr
}

\begin{abstract}
This study aims to propose and examine three basic models for Pre-Concert Rituals (PCRs) that might enhance the audience experience of classical music, as well as provide practical applications for arts marketing professionals. Thus, Experiment 1 examined the effect of audience experiential involvement resulting from pre-concert exposure of the audience to either the music (MUSIC PCR) or the musicians (MUSICIANS PCR) involved through a 10minute video, while Experiment 2 examined the effect of high audience exposure to the music of a performance $(H$. MUSIC PCR) through repeated listening to recordings of the musical pieces prior to the concert performance itself. These findings show that concert experience can be enhanced through the facilitation of MUSICIANS PCR and $H$. MUSIC PCR, regardless of audiences' expertise with classical music.
\end{abstract}

Keywords: performing arts management, audience development, pre-concert lecture

\section{Introduction}

Bernstein (1975), a sociologist, argued that rituals can either be used as a means of distancing one group from another or of uniting one group with another. One of the current limiting factors in achieving greater public access to classical music is that the upper class has exploited concert-going rituals as a way to exclude other classes' access to classical music (DiMaggio and Unseem, 1978).

Since the formation of the field of research in performing arts marketing, theories of sociologists such as Bourdieu, who claims that art appreciation is itself a form of social capital (Colbert, 2017), have steadily attracted attention. In line with Bourdieu, research on the relationship between art consumption and demographic characteristics, such as income, education level, profession, arts expertise, and arts involvement, has been conducted (Kwon \& Bae, 2013; Christin 2012). Many studies in the fields of sociology and music education have suggested arts education as a way to increase prospective customers' familiarity with the arts. Early arts education, however, is not only financially costly, but also demands a substantial commitment of time to achieve the desired outcomes. In addition, the positive effect of arts education on audience satisfaction and repurchase intention of performing arts has not been proved remains unproven.

Based on Söderlud's (2002) study, which argues that higher consumer expertise is associated with higher sensitivity in evaluating a product or service and hence narrower rather than broader arts consumption habits, Hume and Mort (2011) raise the question of whether greater appreciation of the arts actually results in increased rates of re-consumption. Moreover, in the context of visual art, the results of recent empirical studies on the relationship between arts education and museum visitors' actual experience similarly reflect the absence of positive association. Although arts appreciation is found to affect the expectations or attitudes of museum visitors, it has little impact on their actual experience of the visit itself (Tröndel\&Tschacher, 2016). According to Colbert (2017), the research studies conducted in the field of performing arts marketing since 2000 have been primarily focused on areas of consumer behavior and service marketing. These studies have explored the relationships between the factors that determine the quality of performing arts services and audience satisfaction (Minor et al, 2004; Hume and Mort, 2010; Hausman, 2011).

These studies, however, only provide marketing strategies for established attenders and fail to address the needs of non-attenders. Overall, the audience for classical music is aging, and audience size is decreasing. Despite its importance, PCR has been the subject of little investigation in the arts marketing literature.

\section{Conceptual Background}

\section{1. Pre-Concert Ritual}

Structural cultural anthropologists argue that people in all societies conduct boundary rituals, such as honeymoons and funerals, to facilitate transition between absolute binomial categories, such as unmarried/married and life/death. These transitional periods function as experiential examples of the upcoming category, thus serving as adaptation $\mathrm{p}$ eriods for the new members of the category (Fisk, 2010, p. 213-226). 
These rituals also mark boundaries of inclusion and exclusion based on the categorical distinctions and who is and $\mathrm{i}$ s not allowed to cross from one to the other (Collins 2014, p. 297). There is evidence that arts activities exhibit simi lar functions of inclusion and exclusion to foster feelings of attachment to a certain group and distance from other $\mathrm{g}$ roups (Dimaggio and Useem, 1997). PCRs for concert music, therefore, can play the role of boundary rituals for inc lusion.

Rizkallah (2009), in a study of audience development for the Riverside Orchestra, concluded that "creating favourable image in audience members" is important. The key is "interaction and communication." Rizkallah suggested offering promotional packages entailing pre-concert lectures or a pre-concert reception. The purpose of offering a pre-concert lecture is to enhance the audience's understanding of the music to be performed, and the purpose of offering a pre-concert reception is to allow the audience to get to know the performers through everyday conversation. Both of these forms of PCR serve to establish audience inclusion by providing a transitional period that functions as both an experiential example as well as a period of adaptation for members of the non-attender category to identify with the attender category.

For the purposes of this study, PCRs have been classified according to three criteria: 1) whether the PCR is offered as an online or offline resource (online/offline), 2) whether the PCR exposed the audience to the music to be performed, the musicians who will perform it, or both (exposure object: music/musician), and 3) the duration (exposure time) of the PCR. As a survey of relevant current practices, the PCR cases of ten major orchestras are presented according to this classification in Table 1. The most common type of PCR among this sample is a preconcert lecture, typically given by a musicologist or conductor. A second type of PCR is an open talk in which a musician and a musicologist appear together. A third type of PCR is an open rehearsal in which audiences are exposed to both the music and the musicians prior to the programmed performance. The time required for a PCR is anywhere from 5 to 10 minutes for online materials and from 15 minutes to 120 minutes for offline ones.

\section{2. Familiarity with Musicians and Music}

People are more receptive towards familiar situations in which they feel safer at ease (Winkielman, 2003). The reas on people are attracted to someone who has been encountered before or is in some way familiar is because cognitiv e fluent processing decreases the uncertainty (Reber, 2004). Cognitive fluency is simply the ease with which our br ain processes information (Winkielman, 2003). Similarly, consumers tend to prefer performances that have been pr eviously established as worthwhile (Havlena\&DeSarbo, 1991). Featuring a star performer, especially in unpopular genres, has a very positive effect on the ticket sales (Desai and Basuroy, 2005), because of enhanced brand awarene ss and thus audience familiarity (Elberse, 2007, Bapat\&Bapat 2017). Moreover, in addition to contributing to furthe $\mathrm{r}$ relational brand awareness, performances marked by high brand awareness elicit positive sensory, emotional, and behavioral experiences in their audiences (Bapat\&Bapat 2017; Kawahata, 2013).

In determining the liking of music, familiarity has been found to be the most important factor (North and Hargraves , 1995; Peretz et al., 1998; Szpunar et al., 2004). Berlyne (1971), a psychologist, argued that stimuli of intermediate -level familiarity had the highest arousal potential. Following from these results, music that is too familiar may be $\mathrm{f}$ ound to be too simple and boring, while music that is too unfamiliar will be perceived as too complex to stimulate a udience arousal (Madison \& Schölde, 2017). According to Chmiel and Schubert (2017), 50 out of 57 studies on the relationship between complexity of music and audience preferences have shown inverted-U shapes. Up to the inflec tion point, audience liking gradually increases as complexity increases, but once the inflection point is reached, liki ng decreases as complexity increases. A recent study of pop music in terms of complexity and audience preferences , on the other hand, showed that regardless of the complexity of the music, listening to the same song repeatedly res ulted in a steady increase in liking, (Madison \&Schlölde, 2017). In sum, greater exposure to a piece of music, even a highly complex one, increases familiarity and thus liking.

\section{3. Expertise in Classical Music Appreciation}

In marketing literature, expertise is the ability of a customer to perform the tasks associated with the product, and usually the expertise increases when the familiarity of the product increases. Expertise and familiarity are two major components of a customer's knowledge, and familiarity increases when product-related experiences are accumulated (Alba and Hutchison, 1987). Music appreciation is defined as "the ability to distinguish between what is generally accepted by experts as good and bad music (Crickmore, 1968)". Musicality and musical intelligence are required to share musical feeling, which is the goal of music appreciation (Reimer \& Wrights, 1992). Depending on the degree of expertise in music, the complexity of your favorite music also changes; a person with a higher level of expertise in music prefers more complex music (Beryne, 1971). However, the high level of expertise in music may not always allow you to enjoy music. If the expertise of a consumer's musicality is higher the evaluations may be polarized depending on the level of audiences' satisfaction (Södelund, 2002).

\section{4. Hedonic value}


Customer value is based on the overall assessment of what is received compared to what is given (Zaithaml, 1988). The performing arts are hedonic service. The customer value perceived in the hedonic consumption differs than that in utilitarian consumption. In hedonic consumption, customer's emotions have more influence on service quality and customer satisfaction, than consumption of utilitarian service (Yuan \& Wu 2008). The Emotion provides stimulus to behavior and has implication for action, influences information processing, mediates outcome responses (Baggozi et al., 1999).

Therefore, this study defines hedonic value as assessment of felt positive emotion such as feeling happy and delighted compared to felt what is spent such as time and money.

\section{5. Experiential Involvement}

Involvement has been extensively studied in marketing since the 1940s. The research has been conducted mainly on the impact of marketing decisions and on the development of marketing strategies (Pucely et al., 1988). In a study on the consumption of musical goods according to the individual characteristics of Kwon and Chae (2013), the involvement was defined as perceived importance or interest in music in everyday life. Pucely et al. (1988) introduced the concept of experience marketing to measure consumers' involvement in purchasing music. Hausman (2010) also used the concept of experiential marketing to measure the experiential involvement of audiences watching live rock band performances. The author also applied the concept of "flow" by Csikszenmihalyi (2014) to measure the experiential involvement while one is in unconsciousness as well as in consciousness. Flow is "the optimal state" in which people experience intense concentration on what one is doing and are so involved in an activity. Flow is experienced when perceived challenges and the actor's skill are above actor's average levels (Csikszenmihalyi, 2014, pp. 239-264). Hausman (2010) defines watching rock concert as a passive process and experiential involvement as a passive state in his study on Rock concert audience. However, according to James Mursell (1956), "listening classical music is an active process." Thus, we define experiential involvement as an active state.

\section{Experiment 1: Low Level Exposure to Music and Musicians}

\section{1. Conceptual Model and Hypothesis}

Following Rizkallah's (2009) two suggestions for enhancing interaction and communication with audiences, Experiment 1 is designed to study two PCR models (MUSIC PCR and MUSICIANS PCR) and their effects on audience experiential involvement. In addition, a control model (NO PCR) is also included in the study. Each of the two PCR models expose a group of audience members to a 10-minute online video prior to attending a classical concert performance. The content of the MUSIC PCR is designed to increase audience familiarity with specific works of music (North \& Hargreaves, 1995; Chmiel and Schubert, 2017), while the content of the MUSICIANS PCR is designed to increase audience familiarity with specific musicians and thus induce a "star effect" (Elberse, 2007; Bapat\&Bapat, 2017; Desai and Basuroy, 2005).

The following hypotheses are given regarding Experiment 1:

H 1-1: The three different models will have different effects on experiential involvement.

H 1-1a: MUSIC PCR will have a positive effect on experiential involvement compared to the NO PCR control.

H 1-1b: MUSICIANS PCR will have a positive effect on experiential involvement compared to the NO PCR contro 1 .

H 1-1c: MUSIC PCR and MUSICIANS PCR will not have identical effects.

H 1-2: Hedonic value will act as a mediator of the PCR effects on experiential involvement.

H 1-3: Expertise will act as a moderator of the PCR effects on experiential involvement.

\section{2. Data and method}

A convenience sample of 121 Postech undergraduate students enrolled in a required integrated general education course in the fall of 2014 were selected to participate in the experiment. All students were required to attend a concert played by the Pohang city orchestra on November 20, 2014. Measurement data of participants' experiential involvement, hedonic value, and expertise were captured via a questionnaire that participants were required to complete in order to get credit for fulfilling a class assignment. The questionnaire was created by the author using items from scales established in the research literature (Hausman 2010; Zaithaml, 1988; Kwon and Chae, 2013; Hume et al. 2010) and tailored to the context of a classical music concert. The questionnaire was distributed in the lobby of the concert venue before the performance and collected in the same place after the performance. Only the questionnaires submitted by 99 students who arrived on time and completed the survey questionnaire were used for analysis.

\section{3. Stimuli and Procedure}


For testing the effect of MUSIC PCR and MUSICIANS PCR on experiential involvement and hedonic value, the a uthor created two approximately 10-minute long video stimuli. In the MUSICIANS PCR video, the conductor and violin soloist scheduled to perform in the concert appeared and talked about their personal life and their performanc e career. In MUSIC PCR, generic background images were presented accompanied by audio of the main themes of the orchestral music scheduled to be performed in the concert.

Students were divided into three main groups under the restriction that the resulting groups attained equal ratios of gender: two experimental groups (MUSIC PCR, MUSICIANS PCR) and one control group (NO PCR).

In addition, information was collected regarding whether participants had prior knowledge of the musicians by pres enting them with a concert poster which has picture and name of the musicians. Although both the conductor and vi olin soloist were considerably well-known musicians within their fields, no student knew the musicians. The studen ts were not asked whether they had prior knowledge of the music because prompting them with a recording would i nfluence their familiarity with the works, thus compromising the integrity of the experimental design.

The student participants were told that they would have to undertake a team project. During a class meeting, the stu dents were separated into three class rooms according to their experimental and control group assignments. After a discussion concerning their actual team project, each of two experimental groups watched their respective PCR vid eo but the control group had not been exposed to any form of PCR.

\subsection{Results}

\subsubsection{Reliability and Validity of Assessment Instrument}

A pretest was conducted on 32 students who attended Pohang city orchestra in the spring of 2014. The questionnair e was translated into Korean by the author and English words were enclosed in parentheses when the meaning of th e sentence in Korean was not clear. The items were rated on a five-level Likert-type scale. Using SPSS 22.0, the pr etest was performed for reliability with Cronbach's alpha indices exceeding the 0.60 threshold of acceptability. A r eliability test was conducted on all samples of the questionnaire, including those captured in the second experiment described later in this study (Total: $\mathrm{N}=252$, Experiment 1: N=99, Experiment 2: N=181). Factor loadings of items o $\mathrm{n}$ their respective constructs exceeded 0.5 (Anderson and Gerbing 1988). Cronbach's alpha indices exceeding $0.60 \mathrm{i}$ ndicated acceptable reliability (Table 2 ).

\section{4. 2 Hypothesis Testings}

To test hypothesis H1-1, one-way ANOVA was conducted to compare the effect of MUSIC PCR and MUSICIANS PCR (Author's coding: control=0, MUSIC PCR=1, MUSICIANS PCR=2). The means of experimental groups (MUSIC: $\mathrm{N}=31 \mathrm{M}=3.23, \mathrm{SD}=0.69$, MUSICIANS PCR: $\mathrm{N}=34, \mathrm{M}=3.46, \mathrm{SD}=0.70$ ) are higher than that of the control group ( $\mathrm{N}=34, \mathrm{M}=3.06, \mathrm{SD}=)$. The type of PCR (MUSICIANS PCR, MUSIC PCR, and NO PCR) were shown to have a significant effect on experiential involvement at the $\mathrm{P}<0.1$ level $(\mathrm{F}=2.480, \mathrm{P}=0.89)$. Thus $\mathrm{H} 1-1$ is accepted.

To test H1-1a, H1-1b and H1-1c, post-hoc comparisons using a Scheffé test was conducted (Table 3). The mean score of experiential involvement (Figure 1) for the MUSICIANS PCR group was significantly higher than for the NO PCR control group at the $\mathrm{p}<0.1$ level. The difference between the MUSIC PCR group and the control group was not found to be significant. Thus, H1-1a is rejected, while H1-1b and 1-1c are accepted.

To test hypothesis H1-2, regression analysis was conducted by applying Baron and Kenny's (1986) mediating effect analysis method. As Figure 2 illustrates, the standardized regression coefficient between PCR type and experiential involvement was statistically significant $(\beta=0.197, \mathrm{P}=0.028)$, as was that between PCR type and hedonic value $(\beta=0.272, \mathrm{P}=0.00)$, and between hedonic value and experiential involvement $(\beta=0.653, \mathrm{P}=0.00)$. However, the results of a Sobel test indicated that hedonic value was not a significant mediator of the effect of PCR type on experiential involvement $(\mathrm{Z}=0.38, \mathrm{P}=0.702)$. Therefore, $\mathrm{H} 1-2$ was not accepted.

For testing hypothesis H1-3, a two-way ANOVA was conducted on the effects of expertise and PCR type on experiential involvement. Expertise levels included two levels (high/low). Most students thought that their expertise in music was low. Participant responses on the original 5-point scale was were divided into the two levels based on the criteria of $>=3$ for the high group $(n=20)$ and $=<2$ for the low group $(n=45)$. As shown in Table 4 and Figure 3 , the main effects of both expertise and PCR type were not found to be significant ( $>>0.05$ ), whereas the interaction effect was significant, $\mathrm{F}(1,61)=8.359, \mathrm{p}=0.05$ (Ruben, 1986). To confirm the interaction effect between expertise and PCR type, a t-test was conducted for high and low expertise. As a result, in the high expertise group MUSICIANS PCR scored significantly higher than MUSIC PCR with respect to experiential involvement ( $\mathrm{t}=-$ $3.432, \mathrm{p}=0.003$ ); whereas in the low expertise group, there was no significant difference between MUSICIANS PCR vs MUSIC PCR with respect to experiential involvement $(\mathrm{t}=0.372, \mathrm{p}=0.712)$, thus supporting $\mathrm{H} 1-3$. Although 
it was not statistically significant, exposure to MUSIC PCR did show a decrease in levels of experiential involvement for audiences with high expertise.

To summarize the results of Experiment 1, musician-focused content is more effective than music-focused content for PCR models pursue low-level exposure via online video materials. Musician-focused content has a positive effect both on hedonic value and experiential involvement, although hedonic value's mediation effect was not statistically significant, and is most effective for audiences with high expertise.

\section{Experiment 2. High Level Exposure to Music}

\section{1. Conceptual model and Hypothesis}

In Experiment 1, the MUSIC PCR model was not found to significantly improve audience experience of the concert. Experiment 2 was designed to examine whether the effect might be due to the low-level of exposure afforded by a 10-minute online video. Experiment 2 therefore examined the effect of a model of PCR that uses high exposure to music (H. MUSIC PCR) in an offline setting. In order to control for the possible effect of increasing the participants' familiarity with a specific musician, we limited the form of exposure to music only. As shown in previous research, listening to the same song repeatedly should increase audience enjoyment, regardless of musical complexity, due to the increase in familiarity (Madison \&Schlöde, 2017). Therefore, listening to music repeatedly before a performance featuring the same pieces should also increase the measures of hedonic value and experiential involvement as defined in Experiment 1. Higher expertise in music should already entail greater interpretative ability and more positive audience experience, and so participants with this characteristic should not show significant effects due to the H. MUSIC PCR model (Reimer \& Wrights, 1992).

The same survey questionnaire was re-used from Experiment 1. Data collected during Experiment 2 was included, as previously described, in the confirmation analyses for this instrument. The following hypotheses are given regarding Experiment 2:

H 2-1: The participant group exposed to the H. MUSIC PCR model will report higher levels of experiential involvement compared to the NO PCR control group.

\section{H 2-2: Hedonic value will act as a mediator of H. MUSIC PCR's effect on experiential involvement.}

H 2-3: Expertise will act as a moderator of H. MUSIC PCR's effect on experiential involvement.

\section{2. Data and Method}

A convenience sample of 161 Postech undergraduate students enrolled in two different sections of an introductory arts and humanities course in the fall of were selected to participate in the experiment. All students were required to attend a concert played by the Pohang city orchestra on September 10, 2015. Measurement data of participants' experiential involvement, hedonic value, and expertise were captured using the same questionnaire as was used in Experiment 1 . The questionnaire was distributed in the lobby of the concert venue before the performance and collected in the same location after the performance. Students were given attendance credit for attending the performance. Only the questionnaires submitted by 153 students who arrived on time and completed the survey questionnaire were used for analysis.

\section{3. Stimuli and Procedure}

The introductory arts and humanities course from which the participants were selected is a team-teaching course and divided into two sections. The two sections of the course are held at the same time but in two different classrooms. The author served as the instructor in the first section of the course. This section had 82 students and served as the H. MUSIC PCR group for the experiment. Students in the H. MUSIC PCR were given a homework assignment to listen to the music which would be played in the concert performance and were later given a listening quiz based on the music. The second section of the course had 80 students and served as the NO PCR control group for the experiment. Students in the NO PCR control group neither listened to music nor took a listening quiz. The listening quiz taken by the H. MUSIC PCR group students included four multiple-choice questions. Each question prompted the students with audio from one of the main themes of the assigned orchestral pieces. Students were asked to choose the name of the composer and title of the music.

\section{4. Results}

To test hypothesis H2-1, one-way ANOVA was conducted on the effects of the experimental and control group assi gnment on experiential involvement. H. MUSIC PCR was not found to have a significant effect on experiential inv olvement $(\mathrm{F}=0.48, \mathrm{p}=0.828)$. Thus $\mathrm{H} 2-1$ is rejected.

To test hypothesis H2-2, regression analysis was conducted by applying Baron and Kenny's (1986) mediating effect analysis method, as done in Experiment 1. As Figure 4 illustrates, the standardized regression coefficient between PCR type and experiential involvement was not found to be statistically significant $(\beta=-0.29, \mathrm{P}=0.828)$. 
The standardized regression coefficient between PCR type and hedonic value was found to be significant $(\beta=0.208$, $\mathrm{p}=0.042)$, as was that between hedonic value and experiential involvement $(\beta=0.871 \mathrm{P}=0.00)$. The relationship between PCR type and experiential involvement is mediated by hedonic value. Therefore, $\mathrm{H} 2-2$ is accepted.

To test hypothesis H2-3, two-way ANOVA was conducted on the influence of expertise and PCR type on experiential involvement. Level of expertise consisted of two levels (high/low) and PCR type consisted of the one experimental and one control groups.

As in the analysis conducted in Experiment 1, participant responses on the original 5-level scale for expertise were divided into the two levels based on the criteria of $>=2.5$ for the high group $(n=52)$ and $<2.5$ for the low group $(\mathrm{n}=101)$. The main effect was significant $(\mathrm{p}=.000)$, whereas that of familiarity of music was not significant $(\mathrm{p}=0$. 72). The interaction effect was not significant $(\mathrm{P}=0.882)$.

In summary, the effect of the H. MUSIC PCR on experiential involvement was mediated by hedonic value. Familiarity with the music increase with repetition, and the audience experiences optimal status through emotional arousal as a benefit of this familiarity, regardless of expertise.

\section{Conclusion}

\section{1. Discussion}

Before performances, musicians use their own pre-concert rituals as a way of enhancing their ability to perform. Th e positive role that such rituals play should be considered for audiences as well, helping them to immerse themselve $\mathrm{s}$ into the performance. Major classical music organizations already offer some forms of PCR, such as pre-concert 1 ectures, open rehearsals and chatting with artist programs, and arts marketing research and practice have noted the $\mathrm{i}$ mportance of audience education and communication with the audience (e.g., Diamggio and Useem, 1978; Rizkalla h, 2009). However, little research has closely examined the effectiveness of various types of audience-focused PCR s. This research attempts to address this issue in the field of research and draws on recent advances in audience mar keting research and professional practice to examine the effects of three types of audience-focused PCR.

The research confirmed expertise to be one of the significant predictors of better classical music concert experience s, supporting previous conventional studies in arts marketing (DiMaggio and Unseem, 1978; Colbert 2017). It also confirmed that regardless of audience expertise, audience evaluation of their subjective experience can be improved as a result of the increased fluency and familiarity engendered through PCRs (Winkielman, 2003).

Even a low-level online exposure, such as a 10-minute video, can elicit a more positive experience for concert audi ences. Findings showed that the experiential involvement and hedonic value of audiences in the MUSICIANS PCR group increased significantly.

While simply listening to the main theme of a piece of music once or twice for 10 minutes failed to increase the fa miliarity of music or induce greater experiential involvement, familiarity with the music does in fact increase with $\mathrm{r}$ epetition, and the audience benefit from this familiarity, regardless of expertise. Moreover, the effect of this type of MUSIC PCR can be conjectured to have long-term effects because it may also facilitate the audience's contextual $u$ nderstanding of other pieces of music in the same style.

While audience expertise has a generally positive effect on experiential involvement, expertise should not be consid ered the absolute determiner of audience concert experience. The research demonstrates that both MUSICIAN PCR and H. MUSIC PCR can enhance the actual concert experiences of audiences at all levels of expertise.

\section{2. Applications for Arts Management}

The implications of these findings suggest a new approach to performing arts marketing, in that low-cost PCRs mig ht be able to have a substantial effect for potential audiences that do not have a previous background of familiarity with the music being presented. Moreover, the development of ICT technology and the use of new media has made it possible to establish new approaches to audience development.

Providing opportunities for audiences to become familiar with the musicians involved in an upcoming performance, such as through the production of a simple 10-minute online video, can make the audience feel a level of comfort a nd emotional affinity that is not achieved in more academic approaches to the development of music appreciation a nd music education. Of course, the most effective PCR of this type would likely be to facilitate direct in-person inte raction between performers and audiences. Unfortunately, this is likely to interfere with musicians' preparation for performance, including their own PCR practice.

\section{3. Limitations and Further Research}

This research has operationalized in a university of science and technology. Specificity of major, age group and gender of audience were not considered and this could constitute further research. 
Because the two experiments that comprise this study were conducted at different times and with different sample populations, it was not possible to directly compare the effects of music exposure PCRs of different durations. Further examination of the changes in hedonistic value as repeated listening of a piece of music occur would provide more insight into the process of building audience familiarity in fluency. Finally, this study is the first study to examine audience-focused PCRs, and future research could identify further factors audiences' concert experience than those investigated here, for example, emotional arousal, emotional affinity, and expectations.

Other research might also choose to look at whether the PCR models suggested in the study might also be applicable to performing arts genres other than classical music, such as dance or theatre.

\section{References}

Kwon, H. \& Bae, S., (2013). Study on music consumption according to individual personality. Journal of Arts Management, 25, 129-163.

Kim, J. (2009). An analysis of motivation of attending a classical performance as an arts tourism. Journal of Tourism Research, 21(1), 71-92.

Alba, J. W. \& Hutchinson, J. W., (1987). Dimensions of consumer expertise. Journal of Consumer Research, 13(4), 411-454.

Anderson, J. C. \&Gerbing D. W., (1988). Structural equation modeling in practice: A review and recommended two-step approach. Psychological Bulletin, 103(3), 411.

Baggozi, R.P., Gorpinath, M., \&Neyer, P. (1999). The role of emotions in marketing. Psychology of Marketing Science Journal, Vol. 27, No. 2, pp. 184-206.

Archer-Brown, C., Kampani, J., Marder, B., Bal, A. S., \&Kietzmann, J., (2017). Conditions in prerelease movie trailers for stimulating positive word of mouth. Journal of Advertising Research, 57(2), 159-172.

Bapat, D. \&Bapat, D. (2017). Impact of brand familiarity on brands experience dimensions for financial services brands. International Journal of Bank Marketing, 35(4), 637-648.

Baron, R. M. \& Kenny, D. A. (1986). The moderator-mediator variable distinction in social psychological research: Conceptual, strategic, and statistical considerations. Journal of Personality and Social Psychology, 51(6), 1173.

Berlyne, D. E. (1971). Aesthetics and psychology. New York: Appleton-Century-Crofts.

Bernstein, B. (1975). Class, codes and control: Towards a theory of educational transmissions (Vol. 3). London: Routledge \& Kegan.

Brown, M. W. \&Cudeck, R. (1993). Alternative ways of assessing model fit. Sage Focus Editions, 154, 136-162.

Chmiel, A., \& Schubert, E. (2017). Back to the inverted-U for music preference: A review of the literature. Psychology of Music, 45(6), 886-909.

Christin, A. (2012). Gender and highbrow cultural participation in the United States. Poetics, 40(5), 423-443.

Colbert, F. (2017). A brief history of arts marketing thought in North America. The Journal of Arts Management, Law, and Society, 47(3), 167-177.

Collins, R. (2014). Interaction ritual chains. New Jersey: Princeton university press.

Crickmore, L. (1968). An approach to the measurement of music appreciation (I). Journal of Research in Music Education, 16(3), 239-253.

Csikszentmihalyi, M. \& Larson, R. (2014). Flow and the foundations of positive psychology (pp. 209-226). Dordrecht: Springer.

Desai, K. K. \&Basuroy, S. (2005). Interactive influence of genre familiarity, star power, and critics' reviews in the cultural goods industry: The case of motion pictures. Psychology and Marketing, 22(3), 203-223.

DiMaggio, P. \&Useem, M. (1978). Social class and arts consumption. Theory and Society, 5(2), 141-161.

Elberse, A. (2007). The power of stars: Do star actors drive the success of movies? Journal of Marketing, 71(4), 102-120.

Fiske, J. (2010). Introduction to communication studies. Oxon; Routledge.

Hausman, A. (2011). Attribute hedonic value and experiential involvement in evaluations of live musical performance: Theory and managerial implications for services. Journal of Retailing and Consumer Services, 18(3), 210-217.

Havlena, W. J. \&DeSarbo, W. S. (1991). On the measurement of perceived consumer risk. Decision Sciences, 22(4), 927-939.

Hargreaves, D. J. (1984). The effects of repetition on liking for music. Journal of Research in Music Education. 32, $35-47$.

Hayes, D. \& Slater, A. (2002). Rethinking the missionary position'-the quest for sustainable audience development strategies. Managing Leisure, 7(1), 1-17.

Hume, M. \& Sullivan Mort, G. (2010). The consequence of appraisal emotion, service quality, perceived value and hedonic value on repurchase intent in the performing arts. Journal of Services Marketing. 24(2), 170-182. 
Lacher, K. T. \&Mizerski, R. (1994). An exploratory study of the responses and relationships involved in the evaluation of, and in the intention to purchase new rock music. Journal of Consumer Research, 21(2), 366380.

Madison, G. \&Schiölde, G. (2017). Repeated listening increases the liking for music regardless of its complexity: Implications for the appreciation and aesthetics of music. Frontiers in Neuroscience. 11, 147.

Martin, W. E. \&Bridgmon, K. D. (2012). Quantitative and statistical research methods: From hypothesis to results (Vol. 42), San Francisco: John Wiley and Sons.

Meyer, L. B. (2008). Emotion and meaning in music, Chicago: University of Chicago Press.

Minor, M. S., Wagner, T., Brewerton, F. J. \& Hausman, A. (2004). Rock on! An elementary model of hedonic value with musical performances. Journal of Services Marketing, 18(1), 7-18.

Mursell, J. L. (1956). Music education, principles and programs, London: Silver Burdett Co.

Nakamura, J. \&Csikszentmihalyi, M. (2002). Snyder and S.J. Lopez Eds., Flow and the foundations of positive psychology, New York: Oxford University Press.

North, A. C. \& Hargreaves, D. J. (1995). Subjective complexity, familiarity, and liking for popular music. Psychomusicology: A Journal of Research in Music Cognition, 14(1-2), 77.

Karray, S. \&Debernitz, L. (2017). The effectiveness of movie trailer advertising. International Journal of Advertising, 36(2), 368-392.

Kawahata, Y., Genda, E., \& Ishii, A. (2013, July). Revenue prediction of music concerts using the mathematical model of hit phenomena, In biometrics and kansei engineering (ICBAKE). 2013 International Conference on (pp. 208-213). IEEE

Pine, B. J. \& Gilmore, J. H. (1998) Welcome to the experience economy. Harvard Business Review, 76, 97-105.

Peretz, I., Gaudreau, D., \&Bonnel, A. M. (1998). Exposure effects on music preferences and recognition. Memory\& Cognition, 26(5), 884-902.

Reber, R., Wurtz, P., \& Zimmermann, T. D. (2004). Exploring "fringe" consciousness: The subjective experience of perceptual fluency and its objective bases. Consciousness and Cognition, 13(1), 47-60.

Reimer, B. \& Wright, J. E. (1992). On the nature of musical experience, Colorado: University Press of Colorado

Rizkallah, E. G. (2009). A non-classical marketing approach for classical music performing organizations: An empirical perspective. Journal of Business and Economic Research, 7, 111-124.

Söderlund, M. (2002). Customer familiarity and its effects on hedonic value and behavioral intentions. Psychology and Marketing, 19(10), 861-879.

Tröndle, M. \&Tschacher, W. (2016). Art affinity influences art reception (in the eye of the beholder). Empirical Studies of the Arts 34 (1)74-102.

Tudor, A. 1975. Image and influence: Studies in the sociology of film, New York: Allen and Unwin.

Yuan, Y. H. E. \& Wu, C. K. (2008). Relationships among experiential marketing, experiential value, and hedonic value. Journal of Hospitality and Tourism Research, 32(3), 387-410.

Winkielman, P., Schwarz, N., Fazendeiro, T., \&Reber, R. (2003). The hedonic marking of processing fluency: Implications for evaluative judgment. The psychology of evaluation: Affective processes in cognition and emotion, (pp.189-217). Mahwah, NJ:Lawrence Erlbaum Associates, Inc.

Zeithaml, V. A. (1988). Consumer perceptions of price, quality, and value: a means-end model and synthesis of evidence. The Journal of Marketing, 52(3), 2-22. 
$<$ Table 1> Sample of Current PCR Cases

\begin{tabular}{|c|c|c|c|}
\hline Cases & Online/Offline & Exposure object & $\begin{array}{l}\text { Exposure time } \\
(\mathrm{min} .)\end{array}$ \\
\hline $\begin{array}{l}\text { U.S., San Francisco Symphony } \\
\text { "inside music talk" }\end{array}$ & offline & music & 60 \\
\hline $\begin{array}{l}\text { U.S., Charlottesville Symphony } \\
\text { "pre-concert cecture" }\end{array}$ & offline & music & 45 \\
\hline $\begin{array}{l}\text { Canada, Toronto Summer Music } \\
\text { Festival } \\
\text { "open rehearsal" }\end{array}$ & offline & $\begin{array}{l}\text { musicians } \\
\text { music }\end{array}$ & 120 \\
\hline $\begin{array}{l}\text { Germany, Berlin Philharmoniker } \\
\text { "pre-concert talk" }\end{array}$ & online & music & 60 \\
\hline $\begin{array}{l}\text { Canada, Toronto Symphony } \\
\text { "pre-concert chat" }\end{array}$ & online & $\begin{array}{l}\text { musicians } \\
\text { music }\end{array}$ & 10 \\
\hline $\begin{array}{l}\text { Germany, Collegium Musicum Basel } \\
\text { "pre-concert" }\end{array}$ & online & $\begin{array}{l}\text { musicians } \\
\text { music }\end{array}$ & $4-7$ \\
\hline $\begin{array}{l}\text { France, Philharmonie de Paris } \\
\text { "pre-concerts" }\end{array}$ & offline & music & 60 \\
\hline $\begin{array}{l}\text { Korea, Seoul Symphony Orchestra } \\
\text { "pre-concert lecture" }\end{array}$ & offline & music & 40 \\
\hline
\end{tabular}

** Source: homepages of the orchestras, retrieved on December 3, 2<Table 2> Exploratory factor analysis and Reli ability Assessment ( $\mathrm{N}=252)$.

\begin{tabular}{|c|c|c|c|}
\hline Items & Items & Loadings & $\begin{array}{l}\text { Cronbach's } \\
\text { alpha }\end{array}$ \\
\hline \multirow{4}{*}{ Expertise } & E1 & 0.865 & \multirow{4}{*}{0.860} \\
\hline & E2 & 0.775 & \\
\hline & E3 & 0.849 & \\
\hline & E4 & 0.856 & \\
\hline \multirow{5}{*}{$\begin{array}{l}\text { Experiential } \\
\text { Involvement }\end{array}$} & EI1 & 0.67 & \multirow{5}{*}{0.883} \\
\hline & EI2 & 0.805 & \\
\hline & EI3 & 0.815 & \\
\hline & EI4 & 0.837 & \\
\hline & Ei5 & 0.77 & \\
\hline \multirow{4}{*}{ Hedonic value } & HV1 & 0.726 & \multirow{4}{*}{0.788} \\
\hline & HV2 & 0.597 & \\
\hline & HV3 & 0.662 & \\
\hline & HV4 & 0.803 & \\
\hline
\end{tabular}


$<$ Table 3> Post-hoc test

\begin{tabular}{|l|l|l|l|l|l|}
\hline \multirow{4}{*}{ I factor } & J factor & I-J & S.E. & P \\
\hline \multirow{5}{*}{ Scheffé } & \multirow{2}{*}{ NO PCR } & MUSIC PCR & -.1676 & .1818 & .655 \\
\cline { 3 - 6 } & \multirow{3}{*}{ MUSIC PCR } & MUSICIANS PCR & -.3941 & .1776 & .091 \\
\cline { 3 - 6 } & \multirow{2}{*}{ MU PCR } & .1676 & .1818 & .665 \\
\cline { 3 - 6 } & MUSICIANS PCR & NO PCR & .3941 & .1776 & .091 \\
\cline { 3 - 6 } & & MUSIC PCR & .2266 & .1818 & .463 \\
\hline
\end{tabular}

$<$ Table $4>$ The main effects and interaction effect of expertise on experiential involvement

\begin{tabular}{|l|l|l|l|l|}
\hline Independent Variable & DF & Mean Square & F & Sig. \\
\hline PCR Type & 1 & 2.698 & 6.093 & .016 \\
\hline Expertise & 1 & .640 & 1.446 & .234 \\
\hline PCR Type x Expertise & 1 & 3.701 & 8.395 & .005 \\
\hline
\end{tabular}

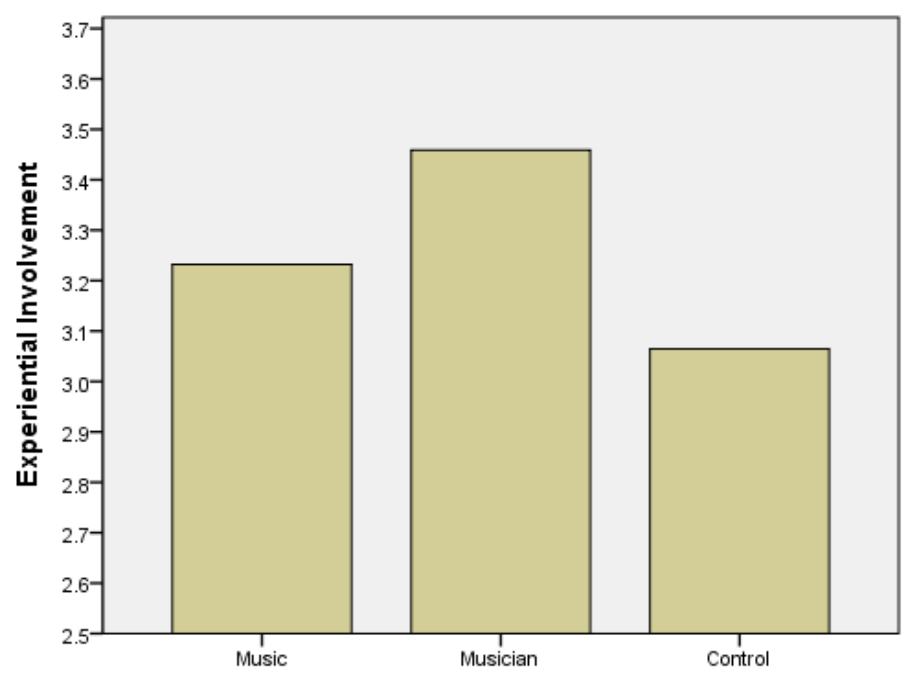

$<$ Figure 1> Mean of Experiential Involvement

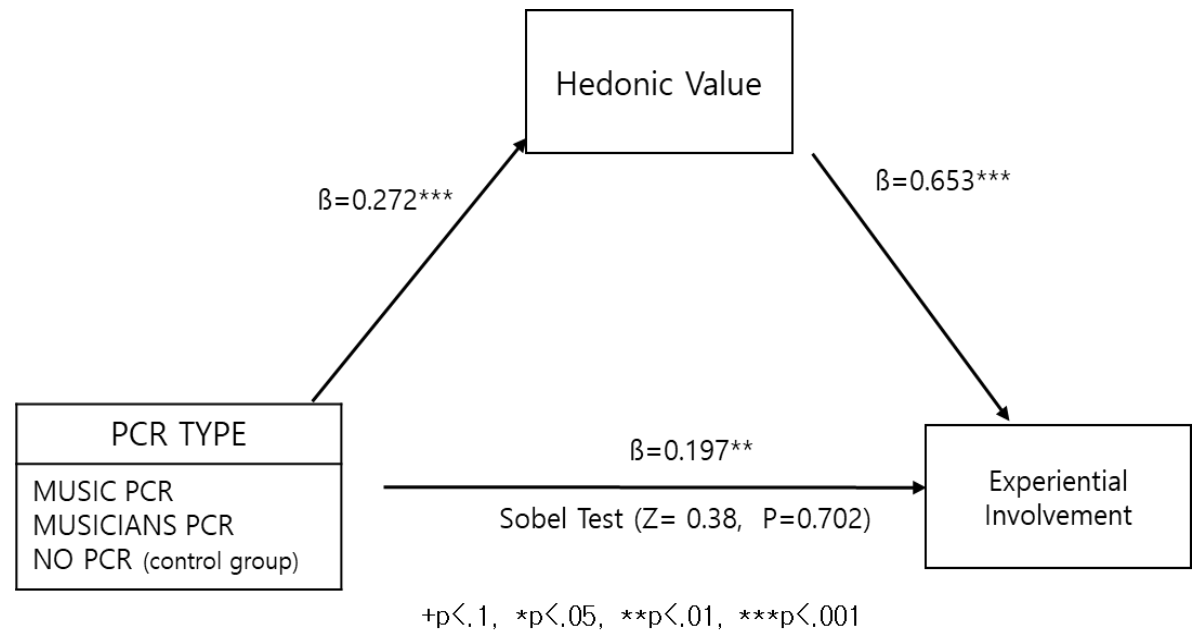


<Figure 2> Result of regression analysis for Experiment 1

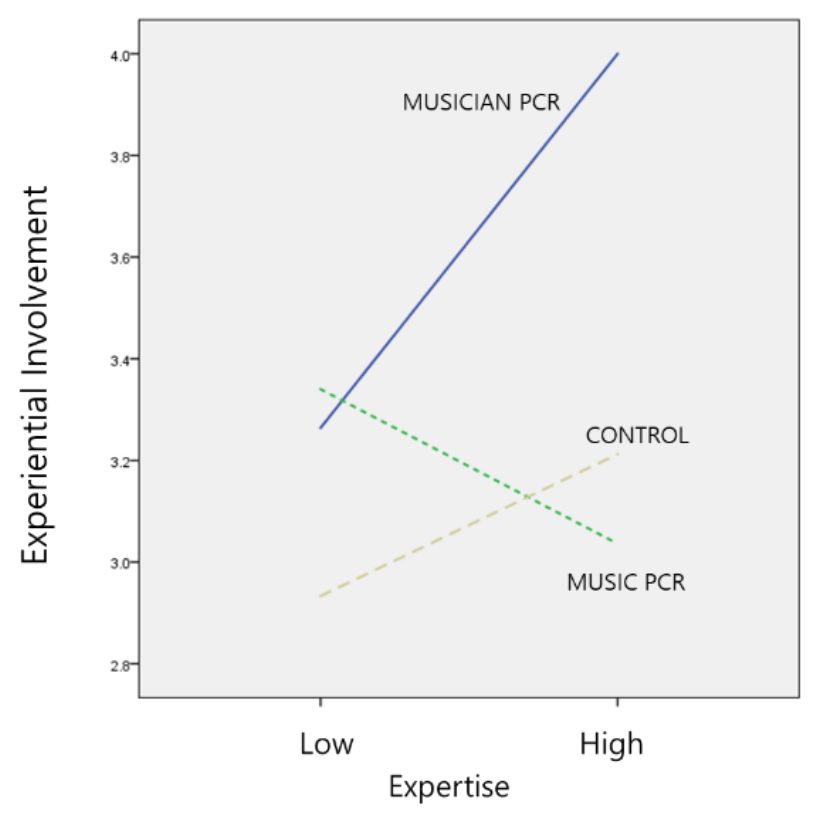

$<$ Figure 3> Interaction effect of expertise

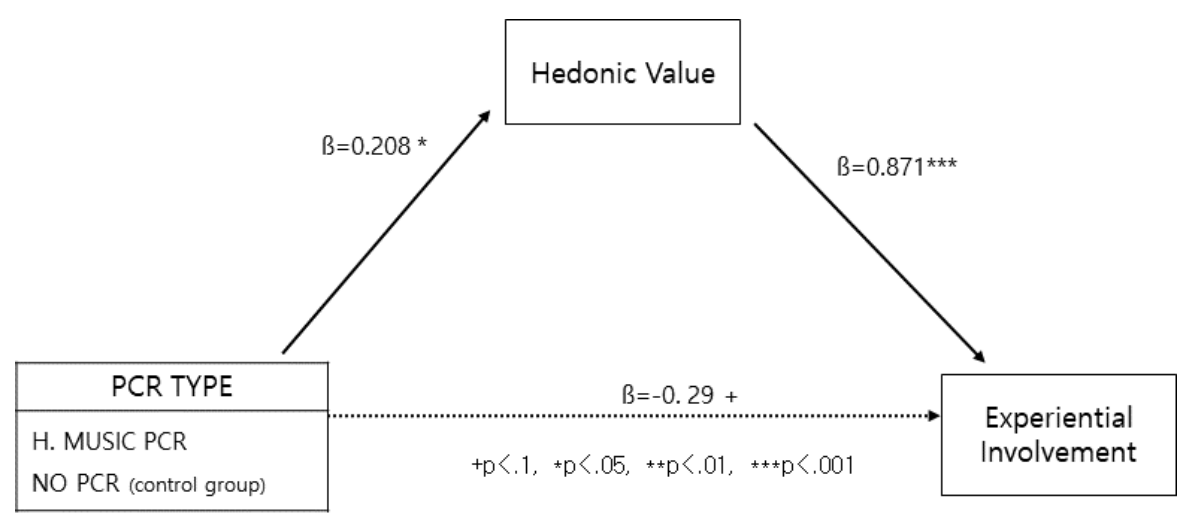

$<$ Figure 4> The result of regression analysis for Experiment 2 